Culture, Personality and Education

МәАәният, шәхес һәм мәгариф

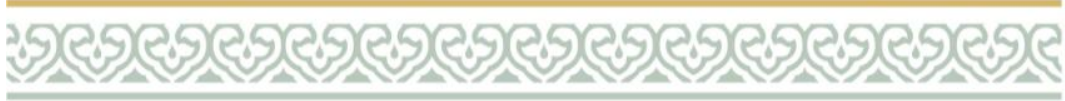

Культура, Аичность и образование

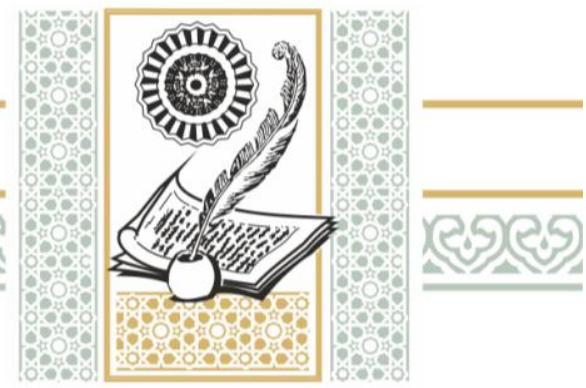

\title{
ADDING A FEW MORE TOUCHES TO ZAKIR KADYRI-UGAN'S CREATIVE BIOGRAPHY
}

\author{
Ismail Turkoglu, \\ Mimar Sinan University of the Arts, \\ Findıkl1, Istanbul, 34427, Turkey, \\ turkogluismail@yahoo.de.
}

\begin{abstract}
The article elaborates the biography of Zakir Halimovich Kadyrov (Kadyri) (1878-1954), a public figure and a teacher. The author of the article conducts a thorough analysis of the scholar's creative activity in the period of forced emigration (1919-1954) and introduces new sources, belonging to $Z$. Kadyri, into the scientific use.
\end{abstract}

Key words: Tatars, Islamic studies, translation studies, national pedagogy, Zakir Kadyri.

The name of Zakir Kadyrov (Kadyri) (18781954), a Tatar public figure and a teacher, was unfairly forgotten and remained banned throughout the Soviet period, for the scholar did not accept the Bolshevik ideology. He was "a highly educated religious leader who knew many oriental languages" and had the experience of teaching in the best Jadid madrasahs. Zakir Kadyri was a talented translator, an author of textbooks and the works that have not lost their relevance today [Vil'danova, p. 3].

In Soviet historiography, the range of Zakir Kadyri studies was not wide, as the scholar shared the fate of many political émigrés, the representatives of the Tatar pre-revolutionary intelligentsia who were caught under the wheels of repressions. One could find scant information about him in the album on the history of the Tatar periodical press by I. Ramiev [Romiev, pp. 28-29], and the manuscript album "Husainiya Madrasa in Orenburg" by M. Rakhimkulova (1975) [Rakhimkulova]. In 1954, an obituary was published in the Turkish newspaper "Turk Yurdu", which described the life and career of Z. Kadyri Ugan [Koshai]. Since the 1990s, articles, devoted to the scholar and his family, have been published in the homeland of the Tatar public figure ([Ytəbai-Kərim], [Мінегулов, 1991, р. 20], [Мінегулов, 1992, р. 18-19], [Mukhamadieva, p. 148], [Gafarova, 2001], [Gaffarova], [Ahmadullin], [Yergin], and others). In 2013, R. K. Vildanova presented her Ph.D. thesis "Zakir Kadyri (1978-1954): Socio-Political and Journalistic Activities", in which the researcher first made a comprehensive biography of the scholar, studied his sociopolitical views, and systematized the bibliography of his works [Vildanova. Zakir Kadyri (1978-1954)]. She has published quite a number of works, devoted to $\mathrm{Z}$. Kadyri [Vil'danova, 2011], [Guseva, Vildanova, pp. 32-35], [Vil'danova. Zakir Kadyri prosvetitel, pp. 144-6], [Saifiev, Vil'danova], [Vildanova, 2015, pp. 338-345], [Vil'danova, 2016, pp. 307-313]. 
The novelty of this research is in the findings that make it possible to eliminate the scholar's biography 'blank spaces', covering the period of his activities abroad. We have systematized research papers on Z. Kadyri, published in Turkey ([Mustafa, pp. 435-438], [Özcan, pp. 76-80], [Mertoğlu, pp. 579-580], [Devlet, pp. 125-126], [Hamit Er], [Güner, pp. 65-94], [Zakir Kadiri Ugan], [Ugan, pp. 318-320], [Maraş, p. 108], [Frederick de Jong, pp.77-84]).

Zakir Kadyri was born on October 2, 1878, in the village of Abdullah of the Simbirsk province, currently the Ulyanovsk region of the Russian Federation. His father, Muhammad Halim Efendi, was a village imam, his mother's name was Mushfika-khanum. From the first marriage of his father, he had three sisters and a brother from his second marriage. Zakir received a primary education in his father's madrasah where he learned to read and write and got the basics of Islamic knowledge. When he grew up, he went to Simbirsk, where he studied in a madrasah at the 1st Simbirsk Cathedral Mosque, in which Vali Mullah (Abdul-Veli Gafarov) was imam and Shakir Ahund (Mohammed-Shakir Gafarov) supervised the work of the madrasah [Kobzev, p. 207]. In 1894, at the request of his father, he went to his uncle's in $\mathrm{Bu}-$ khara and stayed there for five years: he studied the Koran, Hadith, Falsaf, Hikmet, Arabic and Persian. In 1899, according to the wish of an elderly and wealthy benefactor in Bukhara, Zakir Kadyri went to Hajj instead of him, as his proxy. In this way he got a unique opportunity to get acquainted with major Muslim centers. Zakir Kadyri spent two years in Mecca, where Sheikh Iskhak Hindi taught him Hadith and Tafsir, and Edybül-Hejaz Mehmed Ali gave him lessons in Arab literature. On returning from Hijaz, he entered the faculty (illahiyat) of theology at Istanbul University. Zakir Kadyri attended Cemil Sidqi Zehavizade's lectures in Hikmet Islam and, following his advice, went to Egypt, where he attended classes at Al-Azhar University in Cairo. In addition to his lessons at alAzhar and al-Hidiviyah madrasah, he attended the classes of Tantawi Jawheri al-Misri, who gave free lessons to Muslims from Russia. Zakir Kadyri combined his studies in Cairo with journalistic activities: He began to contribute articles about the Muslims of Russia to the newspaper "Al-Liwa" and the journal "Alem ul-Islam". These articles allowed him to earn recognition among the Turkic peoples of Russia. Zakir Kadyri was known in Muslim scientific circles in Russia through Russian pilgrims who went to Hijaz via Cairo.
R. Vildanova notes that the Russian period was the most fruitful in Zakir Kadyri's creative work, it was the time of intense teaching, social and political work. [Vil'danova, Zakir Kadyri ..., p. 3]. When the limited press freedom was allowed in 1905, Turkic and Muslim newspapers and journals appeared in Russia, and modern madrassahs and mektebs were opened. The renowned historian and religious figure Rizaeddin Fakhreddin, who had settled in Orenburg after resigning from the post of Kazyi of the Orenburg Mohammedan Spiritual Assembly in Ufa, invited Zakir Kadyri to teach in the "Husainiya" Madrasah, founded in Orenburg. On returning to Russia at the end of 1906, Zakir Kadyri taught fiqh, philosophy, Hadith and Arabic in the "Husainiya" Madrasah. He also contributed articles to the "at-Tilmiz" newspaper, which was initiated by Abdurashid Ibrahim in St. Petersburg for Muslims who lived in the Russian Empire and did not speak Turkish.

In 1906, Zyya Kamali, a friend of Zakir Kadyri in "Al-Azharu", founded the most modern Muslim madrasah called "Galiya" in Ufa. For a long time Zakir Kadiri would ignore his invitations to move to Ufa, since financially his position in the "Husainiya" Madrasah was very comfortable. Thus, he accepted Zyya Kamali's invitation and moved to Ufa only in 1909. By that time, within the short period of its existence, the "Galia" madrasah had already gained fame among the TurkicTatar peoples, living in Kazakhstan, Kirgyzstan, Turkmenistan and Siberia. Zakir Kadyri became one of the prominent teachers of this madrasah, earning respect and love of his students. At first, he taught Kalam and Arabic, then philosophy, logic, and psychology. In Ufa, he simultaneously taught at the People's University and the "Anasia" Women's Madrasah, where he had classes in the history of Arabs and Islam.

Soon, Zakir Kadyri resumed his journalistic activities: Starting in 1913, he published articles in Vagiz Navruzov's newspaper "Tormysh" ("Life"). In 1914, Zakir Kadyri became the editor-in-chief of "Tormysh" ("Life"). Among the authors of the newspaper were famous poets and writers of that epoch, such as Majit Gafuri, Sagit Ramiyev, Sunchaley, Seyfi Kudash and Sania Giffat tutash. In August 1915, Kadiri began giving lessons in Arabic and Hadith at the "Usmania" madrasah in Ufa.

Describing the Russian period of the scholar's life and work (1916-1918), Rakhimkulova notes that Zakir Kadyrov was a scholar with a broad outlook, he was always well-informed, being a great expert in philosophy, the Arabic language 
and literature, and in the female issue. He wrote the following books: "Гәрәп сарфы" ("Grammar of the Arabic Language", Ufa, 1912), "Гәрәп нәхуә" ("Syntax of the Arabic Language", Ufa, 1912), “Лөгать” (“Arab-Tatar Dictionary”, Ufa).

His creative translation of Herbert Spencer, published in 1911 in Kazan, was one of the series on upbringing. The fact that the Russian translation of this book by Spencer appeared in 1913 makes it possible to conclude that Zakir Kadyrov used the original.

His philophical and social works include: "AtTadjil-Murashsha ...” (Orenburg, 1907) - a philosophical treatise, the translation of the works by Mohammed Ayad Tantawi, Egyptian Professor of St. Petersburg University, "Гыйлме каләм дәресләре" ("Lessons of Kalam", Ufa, 1910)", "Күәт həм рух Kut həm Ruh" ("Strength and Spirit ", Ufa, 1910)², "Низам вә ислам" ("The System and Islam", 1911), "Тормыш hәм дин" ("Life and Religion", 1911), “Формы государственного устройства" ("Forms of the State System", Ufa, 1917) ${ }^{3}$ and others.

His richly illustrated book "Ислам мәдәнияте тарихы" "The History of Culture in the World of Islam", Ufa, 1912-1913) was published in three parts and withstood repeated editions [Rakhimkulova, pp. 75-77].

In 1911, the textbook "Хаят Мухамед галяйсалям" ("The Life of the Prophet Muhammad, Peace be upon Him", Kazan, 1911) was published. It was written by Zakir Kadyri in Orenburg in 1909.

\footnotetext{
${ }^{1}$ While teaching for three years in the Galiya madrasah, Zakir Kadyri faced a lack of lectures on Ilm-Kalyam. He created this work, based on the work of his teacher Muhammad Abdo "Drawat-at-tawhid" and other sources.

${ }^{2}$ After the publication of Gyylme Kaləm Dreslure (Lessons of Kalam, Ufa, 1910), Z. Kadyiri wrote an addition to it based on lectures by Cemil Sidki Zekhavizade, an Istanbul University theologian-teacher of Hikmet Islam, and other scientific books.

${ }^{3}$ The book "Мемлекет идаресе ревешляре" ("Forms of government") (Ufa, 1917) includes such topics as monarchy, constitution, republic as a form of government, the idea of free citizenship, the Montesquieu doctrine, dynasties of monarchs and their rights, members of the city council, the struggle on the path to freedom, the issue of parliamentary elections, two types of parliament, the parliaments of Great Britain and Prussia, the United States of America, federation. At the end of the work a brief information is given on the methods of government, discussed at the First All-Russian Muslim Congress in Moscow in 1917
}

Zakir Kadyri paid great attention to the women's issue. His first works on women were translations of Arabic authors: "Тахрир альмарьәт" ("Liberation of Women") by Kasim Bey Emin and "Маръат аль-джадид” (“A New Woman", Kazan, 1908).

Zakir Kadiri was the author of the book series "A Family Library". As Rakhimkulova points out, Zakir Kadyrov pursued the idea that a woman should be prepared to use freedom; an illiterate, ignorant and ill-mannered woman would be of little use to society, even if she was free. Therefore, while preaching the liberation of women, he paid much attention to women's education (the books: "Кызлар дөньясы" ("The Girls' World”, Kazan, 1911), “ Хатын-кыз мәьсәләсе" ("The Women's Issue", Ufa, 1915), the articles in the newspaper "Тормыш") [Rakhimkulova, pp. 75-77].

Thus, his book "Кызлар дөньясы” ("The Girls' World") [Kadyri. Kyzlar denasy, 1911] discussed girls' education and its impact on their lives. Zakir Kadyri harshly criticized a scholastic education system. The author of the book believed that women should be educated and prepared for the lifestyle required in society. The book consisted of such sections as Tatar girls, the education of girls, influence of girls on social life. The work "Хатын-кыз мәсъәлесе" ("The Women's Issue", Ufa, 1915) presented the outline of the lesson that the author gave on May 1, 1914, in the Muslim branch of Ufa Folk University. Zakir Kadiri addressed it to Muslim women and girls who were not present at the lesson. The notes of the lecture contained the following sections: "Women in the Historical Space", "The Woman in Europe", "The Woman in the East", "Famous Women of the Jahiliyat Era (pre-Muslim ignorance)", "Arab Women in the Era of the Caliphs from the Rashid Family", "Women in the Ancient Turkic World", "Women's Issue in Europe", "Women's Issue in the Islamic World", "Women in Turkey", "Women in Arabic Literature", "Women's Issue among the Tatars" [Kadyri, 1915].

Z. Kadiri actively translated the works of such authors as Tantawi [Tantavi, 1907], [Tantavi, 1908], [Tantavi, 1909], Kasim bey Emin [Emmin, 1908], [Emmin, 1909], Mohammed Abdo [Mohammed, 1909 ], G. Spencer [Spencer, 1911], Rafik Bey [Rafik, 1911], and Georgie Zeidan [Zeidan, 1911].

February 1917 in Russia was the time characterized by active social and political life of the peoples, living in the empire. In 1917-1918, 
Z. Kadyri was an active member of the "Help for Madrasah" society in Orenburg [Rakhimkulova, $\mathrm{p}$. 75]. On March 10, 1917, together with Gumer Teregulov (chairman) and Galimdzhan Ibrahimov (deputy chairman), Zakir Kadyri became a member of the governing board of the Ufa "Committee on the spread of citizenship among Muslims" [Tormysh, 1917, March 12].

On August 15, 1917, in Ufa, the provincial Milli Shuro elected its Executive Committee, which included (the list was compiled in order of the number of votes received) Gumer Teregulov, Zakir Kadyri, Gulmunira Nugayeva, Farkhi Akhmerov, Galimdzhan Ibrahimov, Sagit Salikhov, and Farid Albikov. Supporters of G. Teregulov received a majority at the provincial level. The group of $G$. Ibragimov remained in the provincial Milli Shuro, calling themselves "the left faction of Milli Shuro", thus emphasizing their purely national character [Tormysh, 1917, August 19].

In the autumn of 1917, the "Usmania" madrasah, headed by mudarris J. Abzgildin, actually became the main madrasah of the cultural-national autonomy, where he taught along with a number of other theologians, including G. Barudi, H.-G. Gabyashi, G. Suleymani, Z. Kamali, G. Shnasi, M.-N. Tyuntyari, Z. Kadyri, and M. Hanafi [Tormysh, 1917, September 24].

On October 29-30, 1917, a sitting of the provincial Milli Shuro took place in Ufa, which established its presidium, with G. Teregulov, Z. Kadiri, A.-Z. Validi, G. Ibragimov, F. Saifi and F. Akhmadullin as its members. Thus, among the leadership, three places went to the representatives of the national majority, two - to the Social Revolutionary minority, and one - to the representative of the Bashkir autonomists. The chairmen of the provincial departments of Milli Idarei were elected: Muhtasib Ziya Kamali, Hidayatulla Enikeev, Head of the Department of Malia Nazaraty, and Mardegalim Mukhamedov, Head of the Department of Megarif NazaratY, representing the majority [Tormysh, 1917, October 31].

In Millet Mejlis, there were two groups, which declared the formation of a party: the Turkists and the Tatarists. The faction of Turkists had prerequisites for the formation of a single national party. On December 8, 1917, it was known that the "Turkists party" had been created. To compile the party program, a group of five was elected, consisting of G. Iskhaki, G. Teregulova, Z. Kadyri, H. Maksudi and I. Bikkulova. The Turkists 'message was: "In their national and cultural life, the Turks of Inner Russia and Siberia should go in the natural way under the banner of Turkism, uniting their cultural affairs around this banner without being divided into tribes." In the matter of territorial autonomy, they relied on the Constituent Assembly to issue a decision about the declaration, proclaiming a State on the Volga and in the Southern Urals. The NationalCultural Autonomy was to be realized in Russia in any situation and absolutely autonomously. The Turkists disagreed on the way autonomy was to be realized. In fact, the redistribution of powers was accomplished when the solution to the problem of territorial autonomy was passed on to the socialist members of the Muslim faction in the Constituent Assembly. Other leaders of the faction, led by S. Maksoudi, focused on the activities in Milli Idare [Tormysh, 1917, December 8].

At the All-Russian Muslim Congresses held in Moscow on May 1-11, 1917, and in Kazan on July 21-31, 1917, the Muslims discussed what paths they would follow in the future. Among Muslims there were such groups as the Turkists, Bolsheviks, "Tufrakchylar" (Territorialists) and supporters of "Ittihad al-Islam" (Islamic unity). Zakir Kadyri was a Turkist and in the articles, contributed to the newspaper "Tormysh", he called for territorial autonomy. As a result of congress plenary sessions, the supporters of the national-cultural autonomy took the upper hand and opened the Millet Majlis (the National Assembly) of the Turkic-Tatar Muslims of Inner Russia and Siberia headed by Sadri Maksudi in Ufa. Zakir Kadyri was forced to quit his job in the newspaper "Tormysh" and, in the autumn of 1917, he concentrated on his political activities in the Millet Majlis. In the same year, he married Sania Giffat tutash (1899-1957). Zakir Kadyri was elected a member of the Maharif Nazaraty as part of the Milli Idare (National Directorate).

In April 1918, all newspapers and journals connected with the Millat Majlis were closed. Z. Kadyri was left without a livelihood. After the Ufa meeting on September 23, 1918, with the growing pressure on non-Russian national governments, about twenty people fled to Kyzlyar (Petropavlovsk), including Zakir Kadyri and his wife, Sania Giffat. The spouses with children went to Chita, located near the Chinese border. Dreaming of going back, Zakir Kadyri turned for help to his former students, who had taken the side of the Bolsheviks. According to Rakhimkulova, in his petition, the scholar asked for permission to return, inquiring about any humble job ("be a handle for some broomstick") that he could do at home, but he was denied return [Rakhimkulova, p. 78]. The family of Z. Kadyri was forced to go to the city of 
Hailar in the Chinese province of Manchuria. Having lived there for a year, Zakir Kadiri went to the Turkic-Tatar muhajirs who lived in the town of Gulja in the eastern part of Turkestan (currently the Xinjiang Uygur Autonomous Region of China). There he began teaching the Koran and the history of Islam in the madrasah for the children of the Muhajirs, and his wife, Sania Giffat, gave lessons of her native language.

Zakir Kadiri opened a three-year school for the children of the Turkic-Tatar Muhajirs in Harbin. However, the income earned through his educational activities did not cover all expenses, and the family was in a difficult financial situation. The head of the family, leaving his relatives in Harbin, was forced to move to Turkey in 1922. Sania Giffat and his daughters Azad and Leila joined him only in 1924.

For some time, Zakir Kadyri worked without official registration. In 1924, by order of the Minister of Education he was appointed a member of the Writing and Translation Committee, created by a Decree signed by Prime Minister Ismet Pasha (Inonyu) and President of the Republic Gazi Mustafa Kemal (Ataturk). He was commissioned to prepare for publication a report on the collection known as "Divan-I Türki-i Sultan Veled", written by Sultan Valad (son of Jalaladdin Rumi), compiled by Weled Celebi and amended by Rilate Kilisli (Istanbul 1341). This work of Z. Kadyri was published in the collection of the Theology Faculty (illahiyat) at Istanbul University, where the scholar came to be regularly published. In 1926, the article entitled "Religious and Non-Religious Religious Narratives (Rivayats)" appeared in this journal. A part of this article "Religious Rivayats" was published by Mustafa Karatash [IÜIFD, sy. 4, Istanbul 2001, pp. 207-257], "Non-religious Rivayats" - by Musa Alak [IÜIFD, sy. 4, Istanbul 2001, pp. 259289] with Latin transcription. Additionally, the Turkish magazine "Turk Yord" published his major articles, and, in 1927, Turkish careers were selected for the commission on culture of the "Turkic Societies" (“тюрк очагы”). Freed from his work at the translation commission and after teaching for some time in Tarsus, Zakir Kadyri returned to Ankara and was elected a member of the Turkish Historical Research Commission (Türk Tarihi Tetkik Heyeti), the Turkish Society of Historical Research (Türk Tarihi Tetkik Cemiyeti) established in 1931 (since 1935 more known under the name Türk Tarih Kurumu (Turkish Historical Society).

The Turkish Society of Historical Research commissioned Zakir Kadyri to write a chapter for the four-volume "History of Islam and the Place of Turks in Islam" for high schools. However, this material was not approved by Mustafa Kemal Ataturk, so it was sent to the director of the society with a note "for revision". Zakir Kadyri refused to make adjustments to the material, which was the reason for harsh criticism. As a result, this material was revised by Shamsettin Gunaltay. After that, Zakir Kadyri worked for some time in the Suleymaniyah library in Istanbul, unsuccessfully trying to return to teaching.

In 1936, Zakir Kadyri and his family emigrated to Finland at the invitation of the Finnish Tatars, who felt the need for an imam and teacher from Turkey, since their relations with the Soviet Union were not good. Zakir Kadyri became a teacher at a local Muslim school. He wrote a textbook for immigrants on the history of Turks and Tatars. As pressure exerted on Finland by the USSR increased, Zakir Kadyri was forced to emigrate to Turkey, leaving his family behind. The family reunited in Turkey only in 1944, after Finland had signed a peace treaty with the USSR.

After returning from Finland to Turkey, Zakir Kadyri was engaged in translation activities, which was his only source of income. He worked for the Ministry of Education and the Turkish Historical Society. One part of the translations was printed, the other part is kept in the library of the Turkish Historical Society in manuscripts. Some of his articles were published in the journal "Тюрк йорду".

Zakir Kadyri translated classical works of Islamic scholars "Mukaddima" by Ibn Khaldun [İbn Haldun], "The History of the Prophets and Kings" by at-Tabari [Taberî], "The Book of Conquering Countries" by al-Balazuri [Belâzürî]. He helped Turkologist Ahmet Timer in his work on the book "Kırşehir emiri Caca oğlu Nur el-Din'in 1272 tarihli Arapça-Moğolca vakfiyes" ("ArabicMongol Testament (vakfna charter) 1272 of the Kırşehir Emir Nuretdin") [Kırşehir emiri...]. The scholar worked on the translation of al-Masudi's book "The Golden Placer of Gems", which, unfortunately, was not published [Mesudî ']. Z. Kadyri translated 5308 pages from the "A Complete Set of History" [İbnü'l-Esir'in el-Kamil fi't-tarih]. The scholar translated the work on fiqh "al-Raud" by al-Makdisi [Makdisî '], "The Book of the Ways to Know the Ruling Dynasties" by Makrizi. Z. Kadyri took part in the translation of the fundamental work "The Dawn of Islam" by the Egyptian historian Ahmed Amin: "Fajr-al-Islam', "Spirit-alIslam", "Zuhr-al-Islam" [Emin]. The scholar also translated the work of Count N. Ignatiev, the Rus- 
sian ambassador in Istanbul, on the San Stefano Peace Treaty of 1878 [Graf Nikolay İgnatyev]. Z. Kadiri published his articles in the journal "Türk Yurdu" ("The Türkic House") [Kadiri Ugan Vahabiler], [Kadiri Ugan Çuvaşların Etnografyası], [Kadiri Ugan İdil-Ural...], [Kadiri Ugan Şimal Türk], [Kadiri Ugan Dini ve Gayri...], [Kadiri Ugan Akademi Meselesi], [Kadiri Ugan Etnografyanın], [Kadiri Ugan Türklerin], [Kadiri Ugan Türk Lisanına], [Kadiri Ugan Afganların], [Kadiri Ugan Eski Türk], [Kadiri Ugan Tuna Bulgarlarının]. The scholar also translated articles about Russian writers: M. Gorky [Rus Edibi Maksim Gorki] and L. Tolstoy [Tolstoi].

Zakir Kadyri died in Ankara on October 22, 1954. His wife, the famous Türk-Tatar poetess, Sania Giffat, died on April 12, 1957. They are buried side by side in the Ankara cemetery of Jebeji Asri. Their elder daughter, Azad (Azat) Ugan, married the famous Turkologist Ahmet Temir in 1946. It is known that she died on June 10, 1960. We could not find any information about their younger daughter, Leyla Ugan.

Zakir Kadyri's father, Halim Efendi, was arrested in 1937 for being an imam and because his son had fled abroad. After long interrogations, his house was confiscated despite his venerable age. Halim Efendi was forced to settle in the bath house, next to his former home. He died in 1939. Fate scattered the members of this family across the whole of the USSR.

\section{References}

Ahmed, Emin. Fecrü'l-İslam [Fecrü'l-Islam]. (In Turkish)

Akhmadullin, R. K. (2014). Musul'manskaia intelligentsiia Ufimskoi gubernii: genezis, chislennost' [Muslim Intelligentsia of the Ufa Province: Genesis, Number]. Gramota, No. 4 (42). V 2-kh ch. Ch. I, pp. 20-26. (In Russian)

Azat Ugan. (1957). Prof. Zakir Kadiri Ugan [Prof. Zakir Kadyri Ugan]. Kırım. Sy 9-12, pp. 318-320. Ankara. (In Turkish)

Belâzürî Fütuhu'l Büldan, I-II. Ankara, 1955-1956. (In Turkish)

Devlet, N. (1998). 1917 Ekim Ihtilâli ve Türk-Tatar Millet Meclisi [The October Revolution of 1917 and Turkish-Tatar National Assembly]. Pp. 125-126. İstanbul. (In Turkish)

Ergin, E. V. (2012). Ufimskoe medrese "Usmaniia": $k$ 125-letiiu so dnia otkrytiia [Ufa Madrassah "Usmania": On the 125th Anniversary of Its Opening]. Pedagogicheskii zhurnal Bashkortostana. No. 5 (42), pp. 128-144. (In Russian)

Frederick de Jong. (2004). Transmission of Islamic Learning between Egypt and the Volga-Ural Region in the Early Twentieth Century: The Case of Tantawi
Jawhari and Dhakir al-Qadiri. Islamic Civilisation in the Volga-Ural Region (ed. Ali Çaksu - Rafik Mukhammetshin). Pp. 77-84. İstanbul. (In English)

Gabdukh, Mekhəmməd (1909). Islam və khəiat [Islam and Life]. Orenburg. (In Tatar)

Gafarova, F. Iu. (2004). Tatar mөhaжcirlare [Tatar Poets]. 88 p. Kazan, "Fən" nəshriiaty. (In Tatar)

Gaffarova, F. Iu. (2001). Sadri Maksudi (19061924 ellar) [Sadri Maksudi (1906-1924)]. 262 p. Kazan'. (In Tatar)

Gaffarova, F. Iu. (2001). Zyialy tatar Z. Kadyiri ham khatyn-kyz mas'alase [Enlightened Z. Kadyyri and the Women's Issue]. Tatar ile. No. 3. (In Tatar)

Graf Nikolay Ignatyev'in Ayestefenos. (In Turkish)

Güner, Osman. (2004). Zakir Kadiri Ugan'ın Hadis Sistematiğine Yönelik Eleştirilerinin Tahlil ve Tenkidi [Zakir Kadyri Ugan's Analysis and Criticism of Hadith Systematics]. Ondokuz Mayıs Üniversitesi İlahiyat Fakültesi Dergisi, Sy. 17. Samsun, pp. 65-94. (In Turkish)

Guseva, Iu. N., Vil'danova R. K. (2012). Zakir Kadyri i tiurko-tatarskaia emigratsiia Vostochnoi Azii v nachale 1920-kh gg. [Zakir Kadyri and the Türko-Tatar Emigration of East Asia in the Early 1920s]. Simbirskii nauchnyi vestnik. Ul'ianovsk, UlGU. No. 4 (10), pp. 3235. (In Russian)

Hamit, Er. (1993). İstanbul Darülfunun Ilahiyat Fakültesi Mesmuast Hoca ve Yazarlarl [Istanbul Darülfunun Faculty of Theology Mesmuası Hodja and Authors]. İstanbul, pp. 189-190. (In Turkish)

Hamit, Z. Koşay, (1954). "Zakir Kadiri Ugan" [Zakir Kadyri Ugan]. TY, sy. 239, pp. 428-430. (In Turkish)

İbn Haldun, Mukaddime [The Muqaddimah], I-III. Anlara. 1954-1957. (In Arabic)

İbnü'l-Esir'in el-Kamil fi't-tarih [Ibn al-Esir els alKamil fi't-history]. Ankara. (In Turkish)

Kadyri Ugan Z. (1926). Dini ve Gayri Dini Rivayetler, Birinci Kısım, Gayri Dini Rivayetler [Religions of Religious and Informal Religions. Part One, Informal Religions]. Darülfünun İlahiyat Fakültesi Mecmuasi, c. I, sy 4, pp. 132-210. (In Turkish)

Kadyri Ugan Z. (1954). Afganlarin Kavmi Terkibinde Türklerin Rolü. Türk Yurdu [The Role of Turks in the Development of Afghans]. Sy. 2-235, 1954. S. 127-131; sy. 3-236, s. 234-237; sy. 4-237, pp. 301-304. (In Turkish)

Kadyri Ugan Z. Akademi Meselesi. [Academy Issue]. Türk Yurdu, sy. 1-195, 1928, s. 42-46; sy. 2-196, 1928, s. 35-38; sy. 3-197, 1928, s. 56-58. (In Turkish)

Kadyri Ugan Z. Çuvaşların Etnografyası [Ethnography of the Chuvashes]. Türk Yurdu, sy. 6, 1341, pp. 531-542. (In Turkish)

Kadyri Ugan Z. (1931). Eski Türk Dinine Dair Umay Alihesi [Umay Alihesi on Old Turkish Religion]. Türk Yurdu, sy. 39-233, pp. 17-21. (In Turkish)

Kadyri Ugan Z. (1928). Etnografya ile Alakadar Ilimlerden Mukayese-i Edyan İlmi [Ethnography by Alakadar ilimlerden Mukayese-i Edyan ilmi]. Türk Yurdu , sy. 7-201, pp. 30-35. (In Turkish) 
Kadyri Ugan Z. (1927, 1928). Etnografyanin Inkişafi Tarihi [History of Ethnography]. Türk Yurdu , sy. 4-198, pp. 32-37; sy. 6-200, pp. 33-40. (In Turkish)

Kadyri Ugan Z. (1925). Idil-Ural Boyundaki Türk Lehçeleri Hakkında Bir Tahlil [The Analysis on the Turkish Dialects of Idil-Ural]. Türk Yurdu, sy. 7, 1341, pp. 43-47; sy. 15, pp. 309-322. (In Turkish)

Kadyri Ugan Z. (1926). Şimal Türk Lehçesinde Osmanlı Türkçesinin Tesiri [The Effect of Ottoman Turkish in Turkish Shimal Turkish]. Türk Yurdu, sy. 18, pp. 617-625. (In Turkish)

Kadyri Ugan Z. (1930). Tuna Bulgarlarının Kronolojisi I, II, III [Chronology of the Danube Bulgarians I, II, III]. Türk Yurdu, sy. 27-28, pp. 7-15; sy. 29, pp. 22-29; sy. 30, pp. 5-13. (In Turkish)

Kadyri Ugan Z. (1928). Türk Lisanına Dair Tedkikler [Measures of Turkish Language]. Türk Yurdu, sy. 10-204, pp. 33-35. (In Turkish)

Kadyri Ugan Z. (1928). Türklerin Kavmi ve Kabileleri Terkibi Meselesi [The Turks and the Tribes]. Türk Yurdu, sy. 8-202, pp. 16-19. (In Turkish)

Kadyri Ugan Z. Vahabiler [Wahhabis]. Türk Yurdu. sy. 2, 1340, pp. 123-130; sy. 5, 1341, pp. 389-402. (In Turkish)

Kadyri, Z. (1911). Kyzlar don'iasy [The Girls' World]. Ufa. (In Tatar)

Kadyri. (1915).Khatyn-kyz mos"alese [Women's Issue]. Ufa. (In Tatar)

Kasim bei Emin. (1909). Takhrir al'-mar'st iakhud kadynlarny esaretten azat itu [The Liberation of the Jews from Captivity in Tahrir al-marjata]. Kazan. (In Tatar)

Kasim bei Emin. (1908). Mar"at al'-dzhadid iakhud eni khatyn [Maryat al-Jadid or a New Woman]. Kazan. (In Tatar)

Kırşehir emiri Caca oğlu Nur el-Din'in 1272 tarihli Arapça-Moğolca vakfiyesi (1959) [Arabic-Mongol Testament (vakfna charter) 1272 of the Kırşehir Emir Nuretdin]. Ankara. (In Turkish)

Kobzevy, A. (2013). Mus. Obshchina Simbirska v $X I X-$ nach. $X X v v$. [Muslim Simbirsk Community in the $19^{\text {th }}$ and Early $20^{\text {th }}$ Centuries]. Islam v Povolzh'e. 207 p. Moscow-N. Novgorod, ID Medina. (In Russian)

Koshaiy 3-Kh. (1954). Zakir Kadyri Ugan. 18781954 [Zakir Kadyri Ugan. 1878-1954]. Tiurk iurdu. No.239, pp. 428-431. (In Turkish)

Makdisî' er-Ravzateyn [Makdisî 'er-Ravzateyn]. (1947). Ankara. (In Turkish)

Makrizî' Kitabü's-Sülûk [Makrizî 'KitabüitabsSülûk]. (In Turkish)

Maraşy, İbrahim (2002). Türk Dünyasında Dini Yenileşme (1850-1917) [Religious Renewal in the Turkish World (1850-1917)]. 108 p. İstanbul. (In Turkish)

Mehmet Suat Mertoğlu. Tântavî Cevherî [Tântavî Cevherî]. DİA, c. 39, pp. 579-580. (In Turkish)

Mesudî' Mürûcü'z-zeheb isimli eseri (Paris) (1946)

[Named Mesudî' Mürûcü'z-zeheb]. 1800 p. Ankara. (manuscript). (In Turkish)

Miңnegulov, Kh. Iu. (1991). Saniia Gyiffat [Saniia Gyiffat]. Seembikə No. 2, p. 20. (In Tatar)
Mukhamadieva, F. (1995). Vospominaniia. Iz proshlogo tatar Semirech'ia [Memories. From the Past of the Seven Rivers Tatars].Vestnik Evrazii. No 1, pp. 139-166. (In Russian)

Mustafa Muhammed Allam. (1996). Zakir Kâdirî Ugan Cenapları [Gene of Zakir Kâdirî Ugan.]. Türkiye Cumhuriyeti Dev-letinin Kuruluş ve Gelişmesine Hizmeti Geçen Türk Dünyası Aydınları Sempoz-yumu Bildirileri (23-26 Mayıs). Kayseri, pp. 435-438. (In Turkish)

Ömer, Özcan. (2013). Türkiye Diyanet Vakfi İslam Ansiklopedisi Zakir Kadiri Ugan Maddesindeki Hatalar [Errors in the Encyclopedia of Islamic Religious Foundation of Turkey. Zakir Kadir Ugur's Article]. TY, sy. 311, pp. 76-80. (In Turkish)

Rakhimkulova, M. F. (1997). Zakir Kadyri [Zakir Kadyri]. M. F. Rakhimkulova Medrese "Khusainiia" v Orenburge. Pp. 75-78. Orenburg. (In Russian)

Rus Edibi Maksim Gorki (1928) [Russian Edibi Maksim Gorki]. Hayat, IV, sy 85, 12 Temmuz, pp. 2-3. (In Turkish)

Rəfik bei. (1911). Tormysh khəm din [Life is Also a Religion]. Kazan. (In Tatar)

Rəmiev, I. (1926). Vakytly tatar matbugaty al'bomy (1905-1926) [The Album of the Tatar Periodical Press (1905-1926)]. 56 p. Kazan. (In Tatar)

Saifiev, I. Z., Vil'danova, R. K. (2013). Vozvrashchenie $k$ istokam [Back to the Origins]. $182 \mathrm{p}$. Ul'ianovsk, Kniga. (In Russian)

Spenser, G. (1911). Tarbiia [Education]. Kazan. (In Tatar)

Taberî Milletler ve Hükümdarlar Tarihi (19541958) [The History of British Nations and Monarchs (1954-1958)]. I-IV. Ankara. (In Turkish)

Tantavi Dzhavkheri al'-Misri. (1908). Galimnər, fakikh vo ishanlar vo genchloremez [Scholars, Faqih and Ishans, and Our Youth]. Kazan. (In Tatar)

Tantavi Dzhavkheri al'-Misri. (1909). Nizam vo islam [The System and Islam]. Ufa. (In Tatar)

Tantavi Dzhavkheri al'-Misri. (1907). Әt-taж almurassag bi ж⿻əvakhiri Ker"an va golum [The Crown for the Treasures of the Koran and Knowledge]. Orenburg. (In Tatar)

Tolstoi (1928) [Tolstoy]. Hayat, IV, sy 93, 6 Eylül, pp. 5-7, 16-17. (In Tatar)

Tormysh. (1917) [Tormysh]. 12 marta. (In Tatar)

Tormysh. (1917) [Tormysh]. 19 avgusta. (In Tatar)

Tormysh. (1917) [Tormysh]. 8 dekabria. (In Tatar)

Vil'danova, R. K. (2015). Izuchenie naslediia regional'nykh liderov kak vklad $v$ razvitie istoricheskoi pamiati tatarskogo naroda (na primere Zakira Kadyri) [Studying the Heritage of Regional Leaders as a Contribution to the Development of the Historical Memory of the Tatar Beople (based on the example of Zakir Kadyri)]. Tiurko-musul'manskii mir: identichnost', nasledie i perspektivy izucheniia: sbornik statei Mezhdunarodnoi konferentsii. K 80-letiiu professora M. A. Usmanova. Pp. 338-345. Kazan', izd-vo Kazanskogo universiteta. (In Russian) 
Vil'danova, R. K. (2014). Rol' ufimskoi gazety 'Tormysh' $v$ demokraticheskikh preobrazovaniiakh tiurkskogo obshchestva $v$ 1914-1918 gg. [The Role of the Ufa Newspaper "Tormysh" in the Democratic Reforms of the Turkic Society in 1914-1918]. Vestnik Brianskogo gosudarstvennogo universiteta. No.2, pp. 31-34. (In Russian)

Vil'danova, R. K. (2013). Zakir Kadyri prosvetitel', zhurnalist, obshchestvennyi deiatel' [Zakir Kadyri as an Educator, Journalist, and Public Figure]. Sibirskii nauchnyi vestnik. No. 3 (13), pp. 144-146. (In Russian)

Vil'danova, R. K. (2013). Zakir Kadyri (18781954): obshchestvenno-politicheskaia i zhurnalistskaia deiatel'nost'; avtoref. kand. dis. ... kand. istor. nauk [Zakir Kadyri (1878-1954): Socio-Political and Journalistic Activities: Ph.D. Thesis Abstract]. Kazan', 24 p. (In Russian)
Vil'danova, R. K. (2011). Zakir Kadyri $i$ transformatsiia rossiiskogo obshchestva $v$ nachale 20 veka [Zakir Kadiri and the Transformation of Russian Society in the Early 20th Century]. 158 p. Ul'ianovsk, UlGU. (In Russian)

Vil'danova, R. K. (2016). Zakir Kadyri ob osnovnykh etapakh natsional'nogo dvizheniia tatar // Iz istorii $i$ kul'tury narodov Srednego Povolzh'ia [Zakir Kadyri on the Main Stages of the National Movement of Tatars. From the History and Culture of the Peoples of the Middle Volga]. No. 6, pp. 307-313. (In Russian)

Ytəbai-Kərimi, R. (2008). Şarkiyat Elçisi [Orientalist]. Pp. 28-34. Kazan. (In Turkish)

Ytəbai-Kərimi. (1999). Zakir Kadyri [Zakir Kadyri]. Kyzyl tan. 5 okt. (In Turkish)

“Zakir Kadiri Ugan” (2012) [Zakir Kadyri Ugan].

DİA, cilt 42, pp. 44-45. (In Turkish)

Zəidan Жогжі. (1911).Islam madaniiate tarikhy [The History of Islamic Culture]. 1-3. Ufa. (In Tatar)

\title{
НОВЫЕ ШТРИХИ К ТВОРЧЕСКОЙ БИОГРАФИИ ЗАКИРА КАДЫРИ-УГАНА
}

\author{
Исмаил Тюркоглу, \\ Университет искусств Мимара Синана, \\ Турция, 34427, г. Стамбул, Фындыклы, \\ turkogluismail@yahoo.de.
}

\begin{abstract}
В статье конкретизирована биография общественного деятеля, педагога Закира Халимовича Кадырова (Кадыри) (1878-1954). Автор подробно анализирует творческую деятельность ученого в период вынужденной эмиграции (1919-1954). В научный оборот вводятся новые источники, принадлежащие 3. Кадыри.
\end{abstract}

Ключевые слова: татары, исламоведение, переводоведение, национальная педагогика, Закир Кадыри.

Имя татарского общественного деятеля, педагога Закира Халимовича Кадырова (Кадыри) (1878-1954) было незаслуженно забыто на протяжении всего советского периода, оставалось под запретом, так как ученый не принял идеологию большевиков. Это был «высокообразованный религиозный деятель, знавший многие восточные языки», имевший за своими плечами опыт преподавания в лучших джадидских медресе, талантливый переводчик, автор учебных пособий, сочинений, не потерявших актуальности и в наши дни [Вильданова, с. 3].

Круг исследований о Закире Кадыри в советской историографии был невелик, так как ученый разделил судьбу многих политических эмигрантов, представителей татарской дореволюционной интеллигенции, попавшей под колесо репрессий. Скудные сведения о нем содержались в альбоме об истории татарской пе- риодической печати И. Рамиева [Рәмиев, с. 2829], рукописном альбоме М. Ф. Рахимкуловой «Медресе «Хусаиния» в Оренбурге» (1975) [Рахимкулова]. В 1954 г. в турецкой газете «Тюрк Юрду» был опубликован некролог, где был описан жизненный и творческий путь 3. Кадыри Угана [Кошай]. Начиная с 1990-х гг. на родине татарского общественного деятеля стали появляться статьи, посвященные ученому и его семье ([Үтәбай-Кәрими], [Миңнегулов, 1991, с. 20], [Миңнегулов, 1992, с .18-19], [Мухамадиева, с. 148], [Гафарова, 2001], [Гаффарова], [Ахмадуллин], [Ергин] и др). В 2013 г. Р. К. Вильдановой была защищена кандидатская диссертация «Закир Кадыри (1978-1954): общественно-политическая и журналистская деятельность», в которой впервые была представлена комплексная биография ученого, изучены его общественно-политические взгляды, систе- 
матизирована библиография его трудов [Вильданова. Закир Кыдыри (1978-1954)]. Перу диссертанта принадлежит целый ряд работ, посвященных 3. Кадыри ([Вильданова, 2011], [Гусева, Вильданова, с. 32-35], [Вильданова. Закир Кадыри - просветитель, с. 144-146], [Сайфиев, Вильданова], [Вильданова, 2015, с. 338-345], [Вильданова, 2016, с. 307-313]).

Новизна нашей работы состоит в том, что она позволяет ликвидировать «белые пятна» в биографии ученого за период его деятельности за границей. Мы систематизировали научные работы о 3. Кадыри, опубликованные в Турции ([Mustafa, c. 435-438], [Özcan, c. 76-80], [Mertoğlu, c. 579-580], [Devlet, c. 125-126], [Hamit Er], [Güner, c. 65-94], [Zakir Kadiri Ugan], [Ugan, c. 318-320], [Maraş, c. 108], [Frederick de Jong, c.77-84]).

Закир Кадыри родился 2 октября 1878 года в деревне Абдулла Симбирской губернии, ныне - Ульяновской области Российской Федерации. Его отец Мухаммад Халим Эфенди был деревенским имамом, мать звали Мушфика-ханум. От первого брака отца у него было три сестры и брат от второго брака. Закир получил первичное образование в медресе своего отца, где научился читать и писать и получил основы исламских знаний. Когда он подрос, то отправился в Симбирск, где учился в медресе при 1-й Симбирской Соборной мечети, где имамом был Вали мулла (Абдул-Вели Гафаров), а руководил работой медресе Шакир ахунд (МухаммедШакир Гафаров) [Кобзев, с. 207]. По просьбе своего отца в 1894 году он отправился к своему дяде в Бухару и пробыл там пять лет: изучал Коран, хадис, фальсафу, хикмет, арабский и персидский языки. Согласно пожеланию пожилого и богатого бухарского благотворителя, Закир Кадыри вместо него отправился в хадж по доверенности в 1899 году. Так он получил уникальную возможность познакомиться с крупными мусульманскими центрами. Закир Кадыри два года провел в Мекке, где изучал хадисы и тафсир у шейха Исхак Хинди, брал уроки арабской литературы у Эдибюль-Хиджаз Мехмед Али. Возвратившись из Хиджаза, он поступил на факультет (иллахият) богословия Стамбульского университета. Закир Кадыри слушал лекции по хикмет-исламия у Джемиль Сидки Зехавизаде и, следуя его советам, отправился в Египет, где посещал занятия в каирском университете аль-Азхар. Помимо своих уроков в аль-Азхаре и медресе Аль-Хидивийе он также получал уроки от Тантави Джавхери
аль-Мисри, который давал бесплатные уроки мусульманам из России. Учебу в Каире Закир Кадири совмещал с публицистической деятельностью: он начал писать статьи о мусульманах России для газеты «аль-Лива» и журнала «Алем уль-Ислам». Эти статьи позволили ему заслужить признание среди тюркских народов России. Закир Кадири был известен в мусульманских научных кругах в России через русских паломников, которые отправлялись в Хиджаз через Каир.

«Наиболее плодотворным в творческом отношении, как отмечает Р. К. Вильданова, является российский период, связанный с напряженной преподавательской и общественнополитической работой» 3. Кадыри. [Вильданова. Закир Кадыри..., с. 3]. В связи с принятием ограниченной свободы печати в 1905 в России начали печататься тюркские и мусульманские газеты и журналы, начали открываться современные медресе и мектебы. Известный историк и религиозный деятель Ризаэддин Фахреддин, который поселился в Оренбурге после отставки с должности казыя Оренбургского магометанского духовного собрания в Уфе, пригласил Закира Кадыри преподавать в медресе «Хусаиния», которое было основано в Оренбурге. Вернувшийся в Россию в конце 1906 года, Закир Кадири начал преподавать в медресе «Хусаиния» фикх, философию, хадис и арабский язык. Он также писал статьи для газеты «атТильмиз», которая была создана Абдурашидом Ибрагимом в Санкт-Петербурге для мусульман, которые жили в Российской империи и не говорили по-турецки.

В 1906 году друг Закира Кадыри по «альАзхару» Зыя Камали основал в Уфе самое современное мусульманское медресе под названием «Галия». Закир Кадыри длительное время игнорировал его приглашения переехать у Уфу, так как финансовые возможности медресе «Хусаиния» были очень выгодными. По приглашению Зыя Камали он переехал в Уфу лишь 1909 году. К тому времени медресе «Галия» за короткий срок своего существования успело уже обрести известность среди тюрко-татарских народов, живущих в Казахстане, Кыргызстане, Туркменистане и Сибири. Закир Кадыри стал одним из видных преподавателей этого медресе, снискал уважение и любовь учеников. Вначале он вел уроки по каламу, преподавал арабский язык, а затем философию, логику, психологию. Параллельно в Уфе он преподавал Народном университете и женском медресе «Ана- 
сия», где вел занятия по истории арабов и ислама.

Вскоре Закир Кадыри возобновил свою публицистическую деятельность: начиная с 1913 года, он начал выпускать статьи в газете Вагиза Наврузова ${ }^{1}$ «Тормыш» («Жизнь»). В 1914 г. Закир Кадыри стал главным редактором «Тормыш» («Жизнь»). Среди авторов газеты были известные поэты и писатели эпохи, такие как Маджит Гафури, Сагит Рамиев, Сунчалей, Сейфи Кудаш, Сания Гиффат туташ. С августа 1915 года 3. Кадири начал также давать уроки арабского языка и хадисов в медресе «Усмания〉 в Уфе.

Характеризуя российский период жизни и творчества ученого (1916-1918), М. Ф. Рахимкулова отмечает: «3. Х. Кадыров - ученый с широким кругозором, он всегда в гуще событий, он большой специалист по философии, арабскому языку и литературе и по женскому вопросу. Его перу принадлежат книги: „Гәрәп сарфы“ („Грамматика арабского языка“, Уфа, 1912), „Гәрәп нәхуә“ („Синтаксис арабского языка“, Уфа, 1912), „Лөгать“ („Арабскотатарский словарь“, Уфа).

К циклу воспитания относится его творческий перевод Герберта Спенсера, который вышел из печати в 1911 г. в Казани. Тот факт, что русский перевод этой книги Спенсера вышелв 1913 г., позволяет констатировать, что 3. Х. Кадыров пользовался оригиналом.

К филофским и социальным трудам относятся его книги: „Ат-таджил -мурашша...“ (Оренбург, 1907) - философский трактат, перевод трудов профессора Петербургского университета, египтянина Мухаммеда Айяда Тантави, «Гыйлме каләм дәресләре“ («Уроки калама“", Уфа, 1910)², «Күәт һәм рух“" («Сила и

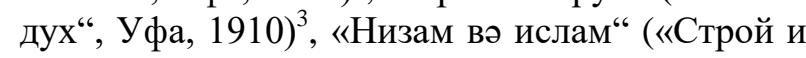

\footnotetext{
${ }^{1}$ После завершения образования в медресе в Стамбуле Вагиз Наврузов переехал в Томск, где выпускал газету под названием «Сибирь», затем после закрытия газеты прибыл в Уфу и создал новую газету под названием «Тормыш» («Жизнь»).

2 Преподавая в течение трех лет в медресе «Галия», Закир Кадыйри столкнулся с отсутствием лекций по «Ильм-Калям». Он создал эту работу, опираясь на работу своего учителя Мухаммада Абдо под названием «Рисалят-ат-таухид» и другие источники.

${ }^{3}$ После издания «Гыйлме каләм дәресләре» («Уроки калама», Уфа, 1910) 3. Кадыйри написал к нему дополнение на основе лекций Джемиль Сидки Зехавизаде богослова-преподавателя Стамбульского университета по хикмет-исламия и других научных книг.
}

ислам“, 1911), «Тормыш һәм дин“ («Жизнь и религия», 1911), «Формы государственного устройства“, Уфа, 1917)

Его богато иллюстрированная книга «Ислам мәдәнияте тарихы“ («История культуры в мире ислама“", Уфа, 1912-1913) вышла в трех частях м выдержала повторные издания» [Рахимкулова, с. 75-77].

В 1911 г. вышло в свет учебное пособие «Хаят Мухамед галяйсалям» («Жизнь пророка Мухаммада, мир ему», Казань, 1911), которая была написана 3. Кадыйри в Оренбурге в 1909 г.

Огромное внимание уделял 3. Кадыри женскому вопросу. Первые его труды, посвященные женщинам, были переводами трудов с арабского таких авторов, как Касим бей Эмин «Тахрир аль-марьәт» («Освобождение женщин»), «Маръат аль-джадид» («Новая женщина», Казань, 1908).

3. Кадыри был автором серии книг «Семейная библиотека». Как указывает М. Рахимкулова, «3. Х. Кадыров проводил в жизнь идею о том, что женщина должна быть готова к использованию свободы; безграмотная, невежественная и невоспитанная женщина будет малополезной обществу, даже если она будет свободна. Поэтому ведя горячую пропаганду об освобождении женщин, он много внимания уделял женскому воспитанию и образованиию» (Книги: «Кызлар дөньясы» («Мир девушек», Казань, 1911), «Хатын-кыз мәьсәләсе» («Женский вопрос», Уфа, 1915), статьи в газете «Тормыш») [Рахимкулова, с. 75-77].

Так, в книге «Кызлар дөньясы» («Мир девушек») [Кадыйри. Кызлар дөньясы, 1911] говорится о воспитании девочек и его влиянии на их жизнь. 3. Кадыри жестко критикует схоластическую систему воспитания. Автор книги считает, что женщины должны быть воспитаны и обучены для образа жизни, потребного в об-

\footnotetext{
${ }^{4}$ Книга «Мемлекет идаресе ревешляре» «Формы государственного устройства» (Уфа, 1917) включает такие темы, как монархия, конституция, республика в качестве форм правления, идея о свободном гражданстве, доктрина Монтескье, династии монархов и их права, члены городского совета, борьба на пути к свободе, вопрос парламентских выборов, два типа парламента, парламенты Великобритании и Пруссии, Соединенные Штаты Америки, федерация. В конце работы собрана краткая информация о способах правления, обсуждаемых на I Всероссийском мусульманском съезде 1917 году в Москве.
} 
ществе. Книга состоит из таких разделов, как татарские девушки, воспитание девушек, влияние девушек на общественную жизнь. Работа «Хатын-кыз мәсьәлесе» («Женский вопрос», Уфа, 1915) представляет конспект урока, который автор дал 1 мая 1914 года в мусульманском отделении Народного университета Уфы. Она была адресована 3. Кадыри мусульманским женщинам и девушкам, которые не присутствовали на уроке. Конспект лекции содержит следующие разделы: «Женщины в историческом пространстве», «Женщина в Европе», «Женщина на Востоке», «Знаменитые женщины эпохи джахилият (домусульманского невежества)», «Арабские женщины в эпоху Халифов рода Рашида», «Женщины в древнем тюркском мире», «Женский вопрос в Европе», «Женский вопрос в исламском мире», «Женщины в Турции», «Женщины в арабской литературе», «Женский вопрос у татар» [Кадыйри, 1915].

3. Кадыри активно переводит труды таких авторов, как Тантави [Тантави, 1907], [Тантави, 1908], [Тантави, 1909], Касим бей Эмин [Эммин, 1908], [Эммин, 1909], Мухаммеда Абдо [Мухаммед, 1909], Г. Спенсер [Спенсер, 1911], Рафик бэй [Рафик, 1911], Джорджи Зейдан [Зейдан, 1911].

В России в феврале 1917 года наблюдается активизация общественно-политической жизни народов, живущих в империи. В 1917-1918 гг. 3. Кадыри был активным членом общества «Помощь медресам» в Оренбурге [Рахимкулова, с. 75]. 10 марта 1917 г. вместе с Гумером Терегуловым (председатель), Галимджаном Ибрагимовым (заместитель председателя), Закир Кадири вошел в правление Уфимского «Комитета по распространению гражданственности среди мусульман» [Тормыш, 1917, 12 марта].

15 августа 1917 г. в Уфе губернское Милли Шуро избрало Исполнительный Комитет, в который вошли (список составлен по числу полученных голосов) Гумер Терегулов, Закир Кадыри, Гульмунира Нугаева, Фархи Ахмеров, Галимджан Ибрагимов, Сагит Салихов, Фарид Альбиков. Сторонники Г. Терегулова получили большинство и на губернском уровне. Группа Г. Ибрагимова оставалась в составе губернского Милли Шуро, называя себя «левой фракцией Милли Шуро» и таким образом подчеркивая свой сугубо национальный характер [Тормыш, 1917, 19 августа].
Осенью 1917 г. медресе «Усмания» под руководством его мударриса Дж. Абзгильдина фактически превратилось в основное медресе культурно-национальной автономии, где, наряду с ним, к преподаванию приступил целый ряд богословов, включая Г. Баруди, Х.-Г. Габяши, Г. Сулеймани, 3. Камали, Г. Шнаси, М.-Н. Тюнтяри, 3. Кадыри, М. Ханафи [Тормыш, 1917, 24 сентября].

29-30 октября 1917 г. в Уфе прошло заседание губернского Милли Шуро, где был создан его президиум, в который вошли Г. Терегулов, 3. Кадыри, А.-3. Валиди, Г. Ибрагимов, Ф. Сайфи и Ф. Ахмадуллин. Таким образом, в руководстве три места получили представители национального большинства, два - эсеровского меньшинства, одно - представитель башкирских автономистов. Были избраны председатели губернских отделов Милли Идарэ: мухтасиб Зыя Камали, глава отдела Малия Назараты Хидаятулла Еникеев и глава отдела Мэгариф Назараты Мардегалим Мухамедов, представлявшие большинство [Тормыш, 1917, 31 октября].

В Миллет Меджлисе о создании партии заявляли две группировки: тюркисты и татаристы. Предпосылки для формирования единой национальной партии имела фракция тюркистов. 8 декабря 1917 г. появляется сообщение о создании «партии тюркистов». Для составления программы выбирается группа из пяти человек в составе Г. Исхаки, Г. Терегулова, 3. Кадыри, Х. Максуди и И. Биккулова. Основным лозунгом тюркистов было: «В национальнокультурной жизни тюрки Внутренней России и Сибири, не разделяясь на племена, должны идти естественным путем под знаменем тюркизма и объединять вокруг этого знамени культурные дела». В вопросе территориальной автономии они оставляли решение о провозглашении Штата на Волге и Южном Урале за Учредительным Собранием. Национально-культурная автономия должна была осуществляться при любом развитии ситуации в России и абсолютно автономно. У тюркистов существовали разногласия по поводу способа автономии. Фактически было совершено перераспределение полномочий, когда решение проблемы территориальной автономии было переложено на социалистов-членов мусульманской фракции в Учредительном Собрании. Другие лидеры фракции во главе с С. Максуди были сосредоточены на деятельности в Милли Идарэ [Тормыш, 1917, 8 декабря]. 
Мусульмане также обсуждали, каким путями в будущем они будут следовать на Всероссийских мусульманских съездах, прошедших в Москве 1-11 мая 1917 года и в Казани 21-31 июля 1917 года. Среди мусульман были такие группы, как тюркисты, большевики, «туфракчылар» (территориалисты) и сторонники «Иттихад аль-Ислам» (исламского единства). Закир Кадири был тюркистом и он выступал в своих статьях в газете «Тормыш» за территориальную автономию. В результате пленарных заседаний съездов сторонники национально-культурной автономии одержали победу и под руководством Садри Максуди открыли в Уфе Миллет Меджлисе (Национальное Собрание) тюркотатар мусульман Внутренней России и Сибири. Закир Кадири был вынужден оставить свою деятельность в газете «Тормыш» и сосредоточиться осенью 1917 г. на политической деятельности в Миллет Меджлисе. В том же году он женился на Сание Гиффат туташ (18991957). Закир Кадири был избран членом Магариф Назараты в составе Милли Идарэ (Национального Управления).

С апреля 1918 года все газеты и журналы, связанные с Миллет Меджлисе, были закрыты. 3. Кадыри остался без средств к существованию. После Уфимского совещания 23 сентября 1918 года, когда началось давление на нерусские национальные правительства, порядка 20 человек бежали в Кызылъяр (Петропавловск), в том числе Закир Кадыри и его жена Сания Гиффат. Супруги с детьми отправились в Читу, расположенную рядом с китайской границей. Мечтая вернуться назад, Закир Кадыйри обратился за помощью к бывшим ученикам, которые перешли на сторону большевиков. Как указывает М. Ф. Рахимкулова, в своем прошении ученый просил разрешения вернуться: «сможет ли еще быть черенком для какой-нибудь метлы в новом строе у себя на родине», но ему было отказано в возвращении [Рахимкулова, с. 78]. Семья 3. Кадыри была вынуждена отправиться в город Хайлар в китайской провинции Маньчжурия. Прожив здесь год, Закир Кадыри отправился к тюркско-татарским мухаджирам, которые жили в городе Кульджа в восточной части Туркестана (ныне Синьцзян-Уйгурский автономный район Китая). Здесь он начал преподавать в медресе для детей мухаджиров Коран и историю Ислама, а его жена - Сания Гиффат - давала уроки родного языка.

Закир Кадыри открыл в Харбине трехклассную школу для детей тюркско-татарских му- хаджиров. Однако доходы от образовательной деятельности не покрывали всех расходов, и семья попала в затруднительное материальное положение. Глава семьи, оставив родных в Харбине, вынужден был в 1922 г. уехать в Турцию. Сания Гиффат с дочерьми Азадой и Лейлой к нему присоединились лишь в 1924 году.

Закир Кадыри некоторое время работал неофициально. 23.06.1340 (1924) Распоряжением Министра образования он был назначен в комиссию по делам сочинений и переводов, созданную Декретом, подписанным премьерминистром Исметом пашой (Иненю) и Президентом Республики Гази Мустафой Кемалем (Ататюрком). Ему было поручено подготовить к печати доклад о сборнике Султана Валада (сына Джалаладдина Руми), составленном Веледом Челеби и исправленном Рифатом Килисли, известный как «Divan-I Türki-i Sultan Veled» (Istanbul 1341). Этот труд 3. Кадири был опубликован в сборнике факультет (иллахият) богословия Стамбульского университета, где он начал регулярно публиковаться. В 1926 году в этом журнале была опубликована статья «Религиозные и нерелигиозные религиозные повествования (риваяты)». Часть этой статьи «Религиозные риваяты» была опубликована Мустафой Караташем [IÜIFD, sy. 4, Стамбул 2001, c. 207-257], «Не религиозные риваяты» Мусой Алаком [IÜIFD, sy. 4, Стамбул 2001, с. 259289] с транскрипцией на латинице. С другой стороны, в турецком журнале «Тюрк йорду» были опубликованы его основные статьи, и в 1927 году турецкие карьеры были выбраны для комиссии по культуре «Тюркских обществ» («тюрк очагы»). Освободившись от деятельности в комиссии по переводам после некоторого времени преподавания в Тарсусе, Закир Кадири снова вернулся в Анкару и был избран членом Турецкой комиссии исторических исследований (Türk Tarihi Tetkik Heyeti), Турецкого общества исторических исследований (Türk Tarihi Tetkik Cemiyeti) созданной в 1931 году (более известно под названием с 1935 г. Türk Tarih Kurumu (Турецкое историческое общество).

Турецкое общество исторических исследований поручило написать Закиру Кадыри главу для четырехтомника «История Ислама и место в Исламе тюрок» для лицеев. Однако это материал не был одобрен Мустафой Кемалем Ататюрком, поэтому был отправлен директору общества с пометкой «на доработку». Закир Кадыри отказался внести коррективы в материал, что стало поводом для жесткой критики. В ре- 
зультате данный материал был переработан Шамсеттином Гуналтаем. Закир Кадыри после этого некоторое время работал в библиотеке Сулеймания в Стамбуле, пытался безуспешно вернуться на преподавательскую деятельность.

Закир Кадыри в 1936 г. вместе с семьей эмигрировал в Финляндию по приглашению финских татар, которые испытывали потребность в имаме и учителе из Турции, так как отношения с Советским Союзом не были хорошими. Закир Кадири стал преподавателем в местной мусульманской школе. Он написал для эмигрантов учебник по истории тюрок и татар. В связи с усилением давления СССР на Финляндию Закир Кадири, оставив семью, был вынужден эмигрировать в Турцию. Семья воссоединилась в Турции лишь в 1944 г., после подписания Финляндией мирного договора с СCCP.

После возвращения из Финляндии в Турцию Закир Кадыри посвятил себя переводческой деятельности, что послужило для него единственным источником доходов. Он выполнял заказы для Министерства образования и Турецкого исторического общества. Часть из переводов была напечатана, а часть в рукописном виде хранится в библиотеке Турецкого исторического общества. Некоторые его статьи увидели свет в журнале «Тюрк йорду».

Закир Кадыри переводил классические труды исламских ученых «Мукаддима» Ибн Халдуна [İbn Haldun], «История пророков и царей» ат-Табари [Taberî], «Книга завоевания стран» аль-Балазури [Belâzürî]. Он помогал тюркологу Ахмету Тимеру в работе над книгой «Kırşehir emiri Caca oğlu Nur el-Din'in 1272 tarihli ArapçaMoğolca vakfiyes» («Арабско-монгольское завещание (вакфная грамота) 1272 г. кыршехирского эмира Нуретдина») [Kırşehir emiri...]. Ученый работал над переводом книги аль-Масуди «Золотые россыпи самоцветов», который, к сожалению, не был опубликован [Mesudî']. 3. Кадыйри перводил 5308 страниц из «Полного свода истории» [İbnü'l-Esir'in elKamil fi't-tarih]. Ученый перевел труд по фикху «ар-Рауда» ал-Макдиси [Makdisî’], «Книгу путей к познанию правящих династий» Макризи. 3. Кадыри принимал участие в переводе фундаментального труда египетского историка Axмеда Амина «Рассвет ислама»: «Фаджр-алИслам», «Духа-ал-Ислам», «Зухр-ал-Ислам» [Emin]. Ученый переводил произведение русского посла в Стамбуле графа Н. Игнатьева, посвященное Сан-Стефанскому мирному дого- вору 1878 г. [Graf Nikolay İgnatyev]. 3. Кадыри печатал свои статьи в журнале «Тюрк юрду» («Тюркский дом») [Kadiri Ugan Vahabiler], [Kadiri Ugan Çuvaşların Etnografyası], [Kadiri Ugan İdil-Ural...], [Kadiri Ugan Şimal Türk], [Kadiri Ugan Dini ve Gayri...], [Kadiri Ugan Akademi Meselesi], [Kadiri Ugan Etnografyanın], [Kadiri Ugan Türklerin], [Kadiri Ugan Türk Lisanına], [Kadiri Ugan Afganların], [Kadiri Ugan Eski Türk], [Kadiri Ugan Tuna Bulgarlarının]. Пeру ученого принадлежит перевод статей о русских писателях М. Горьком [Rus Edibi Maksim Gorki] и Л. Толстом [Tolstoy].

Закир Кадыри скончался в Анкаре 22 октября 1954 года. Его супруга, известная тюркотатарская поэтесса, Сания Гиффат скончалась 12 апреля 1957 года. Они похоронены рядом на кладбище Анкары Джебеджи Асри. Старшая дочь Азаде (Азат) Уган в 1946 г. вышла замуж за знаменитого тюрколога Ахмета Темира. Известно, что она скончалась 10 июня 1960 года. О младшей дочери Лейлы Уган сведений обнаружить нам не удалось.

Отец Закира Кадыри Халим Эфенди был арестован в 1937 году за то, что был имамом, за то, что его сын сбежал за границу. После долгих допросов, несмотря на почтенный возраст, его дом был конфискован. Халим Эфенди вынужден был поселиться в бане, рядом со своим бывшим домом. Он умер в 1939 году. Судьба разбросала членов этой семьи по просторам CCCP.

\section{Литература}

Ахмадуллин P. K. Мусульманская интеллигенция Уфимской губернии: генезис, численность // Грамота, 2014. № 4 (42): в 2-х ч. Ч. І. С. 20-26.

Вильданова Р. К. Закир Кадыри - просветитель, журналист, общественный деятель // Сибирский научный вестник. 2013. № 3 (13). С. 144-146.

Вильданова Р. К. Закир Кадыри (1878-1954): общественно-политическая и журналистская деятельность; автореф. канд. дис. ... канд. истор. наук. Казань, 2013. 24 с.

Вильданова P. К. Закир Кадыри и трансформация российского общества в начале 20 века. Ульяновск: УлГУ, 2011. 158 с.

Вильданова Р. К. Закир Кадыри об основных этапах национального движения татар // Из истории и культуры народов Среднего Поволжья. 2016. № 6. C. 307-313.

Вильданова Р. К. Роль уфимской газеты «Тормыш» в демократических преобразованиях тюркского общества в 1914-1918 гг. // Вестник Брянского государственного университета. 2014 № 2 С. 31-34.

Вильданова Р. К. Изучение наследия региональных лидеров как вклад в развитие исторической па- 
мяти татарского народа (на примере Закира Кадыри) // Тюрко-мусульманский мир: идентичность, наследие и перспективы изучения: сборник статей Международной конференции. К 80-летию профессора М. А. Усманова. Казань, изд-во Казанского университета, 2015. С. 338-345.

Гусева Ю. Н., Вильданова Р. К. Закир Кадыри и тюрко-татарская эмиграция Восточной Азии в начале 1920-х г.г. // Симбирский научный вестник. Ульяновск: УлГУ. 2012. № 4 (10). С. 32-35.

Ергин E. В. Уфимское медресе «Усмания»: к 125 -летию со дня открытия // Педагогический журнал Башкортостана. 2012. № 5 (42). С. 128-144.

Кобзев A. Мус. Община Симбирска в XIX - нач. XX вв. // Ислам в Поволжье: М.-Н. Новгород: ИД Медина, 2013. С. 207.

Мухамадиева Ф. Воспоминания. Из прошлого татар Семиречья // Вестник Евразии. № 1. 1995. С. 139-166.

Рахимкулова М. Ф. Закир Кадыри // М. Ф. Рахимкулова Медресе «Хусаиния» в Оренбурге. Оренбург, 1997. С. 75-78.

Сайфиев И. З., Вильданова Р. К. Возвращение к истокам. Ульяновск: Книга, 2013. 182 с. 1909.

Габдух Мөхәммәд. Ислам вә хәят. Оренбург,

Гафарова Ф. Ю. Татар мөһажирләре. Казан: «Фән» нәшрияты, 2004. 88 б.

Гаффарова Ф. Ю. Зыялы татар 3. Кадыйри һәм хатын-кыз мәсьәләсе // Татар иле. 2001. № 3.

Гаффарова Ф. Ю. Садри Максуди (1906-1924 еллар). Казань, 2001. 262 б.

Зәйдан Жоржси. Ислам мәдәнияте тарихы. 1-3. Уфа, 1911.

Кадыйри 3. Кызлар дөньясы. Уфа, 1911

Кадыйри. Хатын-кыз мәсьәлесе. Уфа, 1915.

Касим бей Эмин. Тахрир аль-марьәт яхуд кадынларны эсареттен азат иту. Казан, 1909.

Касим бей Эмин. Маръат аль-джадид яхуд ени хатын. Казан, 1908.

Кошай 3-X. Закир Кадыри Уган. 1878-1954 // Тюрк юрду. 1954. № 239. С. 428-431.

Миңнегулов Х. Ю. Сания Гыйффәт // Сөембикә. 1991. № 2. C. 20.

Рдмиев И. Вакытлы татар матбугаты альбомы (1905-1926). Казан, 1926. 56 б.

Рәфик бей. Тормыш хәм дин. Казан, 1911.

Спенсер Г. Тәрбия. Казан, 1911.

Тантави Джавхери аль-Мисри. Галимнәр, факих вә ишанлар вә генчләремез. Казан, 1908.

Тантави Джавхери аль-Мисри. Әт-таж әлмурассаг би жәвахири Көръан вә голум. Оренбург, 1907.

Тантави Джавхери аль-Мисри. Низам вә ислам. Уфа, 1909.

Тормыш. 1917. 12 марта.

Тормыш. 1917. 19 августа.

Тормыш. 1917. 8 декабря.

Үтәбай-Кәрими. Закир Кадыри // Кызыл тан. 1999. 5 окт.
Үтәбай-Кәрими P. Şarkiyat Elçisi, Казан, 2008, С. 28-34.

Ahmed Emin. Fecrü'l-İslam.

Azat Ugan. Prof. Zakir Kadiri Ugan // Kırım. Sy 9-

12. Ankara, 1957. s. 318-320.

Belâzürî Fütuhu'l Büldan, I-II. Ankara, 1955-1956.

Devlet N. 1917 Ekim İhtilâli ve Türk-Tatar Millet Meclisi. İstanbul 1998. s. 125-126.

Graf Nikolay İgnatyev'in Ayestefenos.

Güner Osman. Zakir Kadiri Ugan'ın Hadis Sistematiğine Yönelik Eleştirilerinin Tahlil ve Tenkidi // Ondokuz Mayıs Üniversitesi İlahiyat Fakültesi Dergisi, Sy. 17. Samsun, 2004. S. 65-94.

Hamit Er. İstanbul Darülfunun İlahiyat Fakültesi Mesmuası Hoca ve Yazarları. İstanbul, 1993. S. 189190.

Hamit. Z. Koşay, «Zakir Kadiri Ugan», TY, sy. 239 (1954). S. 428-430.

İbn Haldun, Mukaddime, I-III. Anlara. 1954-1957.

İbnü'l-Esir'in el-Kamil fi't-tarih, Ankara.

Kadiri Ugan Z. Dini ve Gayri Dini Rivayetler, Birinci Kısım, Gayri Dini Rivayetler // Darülfünun İlahiyat Fakültesi Mecmuası, c. I, sy 4, 1926. S. 132210.

Kadiri Ugan Z. Afganların Kavmi Terkibinde Türklerin Rolü // Türk Yurdu, sy. 2-235, 1954. S. 127131; sy. 3-236, 1954, s. 234-237; sy. 4-237, 1954, s. 301-304.

Kadiri Ugan Z. Akademi Meselesi // Türk Yurdu, sy. 1-195, 1928, s. 42-46; sy. 2-196, 1928, s. 35-38; sy. 3-197, 1928, s. 56-58.

Kadiri Ugan Z. Eski Türk Dinine Dair Umay Alihesi // Türk Yurdu, sy. 39-233, 1931, s. 17-21.

Kadiri Ugan Z. Etnografya ile Alakadar İlimlerden Mukayese-i Edyan İlmi // Türk Yurdu, sy. 7-201, 1928, s. 30-35.

Kadiri Ugan Z. Etnografyanın İnkişafı Tarihi // Türk Yurdu , sy. 4-198, 1927, s. 32-37; sy. 6-200, 1928, s. 33-40

Kadiri Ugan Z. Şimal Türk Lehçesinde Osmanlı Türkçesinin Tesiri // Türk Yurdu, sy. 18, 1926, s. 617625.

Kadiri Ugan Z. Tuna Bulgarlarının Kronolojisi I, II, III // Türk Yurdu, sy. 27-28, 1930, s. 7-15; sy. 29, s. 22-29; sy. 30, s. 5-13.

Kadiri Ugan Z. Türk Lisanına Dair Tedkikler // Türk Yurdu, sy. 10-204, 1928, s. 33-35.

Kadiri Ugan Z. Türklerin Kavmi ve Kabileleri Terkibi Meselesi // Türk Yurdu, sy. 8-202, 1928, s. 1619.

Kadiri Ugan Z. Çuvaşların Etnografyası // Türk Yurdu, sy. 6, 1341, s. 531-542.

Kadiri Ugan Z. İdil-Ural Boyundaki Türk Lehçeleri Hakkında Bir Tahlil // Türk Yurdu, sy. 7, 1341, s. 4347; sy. 15, 1925, s. 309-322.

Kadiri Ugan Z. Vahabiler // Türk Yurdu. sy. 2, 1340, s. 123-130; sy. 5, 1341, s. 389-402.

Kırşehir emiri Caca oğlu Nur el-Din'in 1272 tarihli Arapça-Moğolca vakfiyesi Ankara, 1959.

Makdisî' er-Ravzateyn. Ankara, 1947. 
Makrizî' Kitabü’s-Sülûk

Maraş Ibrahim. Türk Dünyasında Dini Yenileşme (1850-1917). İstanbul, 2002. S. 108.

Mehmet Suat Mertoğlu. Tântavî Cevherî, DİA, c. 39, s. 579-580.

Mesudî' Mürûcü'z-zeheb isimli eseri (Paris), Ankara, 1946. 1800 s. (не опубликовано)

Mustafa Muhammed Allam. Zakir Kâdirî Ugan Cenapları”. Türkiye Cumhuriyeti Dev-letinin Kuruluş ve Gelişmesine Hizmeti Geçen Türk Dünyası Aydınları Sempoz-yumu Bildirileri (23-26 Mayıs). Kayseri, 1996. S. 435-438.

Rus Edibi Maksim Gorki // Hayat, IV, sy 85, 12 Temmuz, 1928. S. 2-3.
Taberî Milletler ve Hükümdarlar Tarihi, I-IV. Ankara, 1954-1958.

Tolstoy // Hayat, IV, sy 93, 6 Eylül, 1928. S. 5-7, 16-17.

Ömer Özcan. Türkiye Diyanet Vakfı İslam Ansiklopedisi Zakir Kadiri Ugan Maddesindeki Hatalar, TY, sy. 311, (2013). S. 76-80.

«Zakir Kadiri Ugan», DIA, cilt 42, (2012). S. 4445

Frederick de Jong. Transmission of Islamic Learning between Egypt and the Volga-Ural Region in the Early Twentieth Century: The Case of Tantawi Jawhari and Dhakir al-Qadiri" // Islamic Civilisation in the Volga-Ural Region (ed. Ali Çaksu - Rafik Mukhammetshin). İstanbul, 2004. S. 77-84.

\section{ЗАКИР КАДЫЙРИ-УГАННЫН ИЖАТ БИОГРАФИЯСЕНӘ ЯНА ШТРИХЛАР}

Исмаил Төркоглу,

Мимар Синан исемендәге Нәфис сәнгать университеты Төркия, 34427, Истанбул ш., Фындыклы, turkogluismail@yahoo.de.

Мәкаләдә жәмәгать эшлеклесе, педагог Закир Хәлим улы Кадыйровның (Кадыйри) (18781954) тәржемәи хәленә төгәллек кертелә. Мөһажирлеккә китәргә мәжбүр булган галимнең 1919-1954 еллардагы ижат эшчәнлеге автор тарафыннан жентекле рәвештә анализлана. 3. Кадыйрига караган яңа чыганаклар фәнни әйләнешкә кертелә.

Төп төшенчәләр: татарлар, ислам гыйлеме, тәржемә белеме, милли педагогика, Закир Кадыйри. 